\title{
Gambaran Hematologi Tikus Putih (Rattus norvegicus) yang Diinfeksi Escherichia coli Enteropatogenik dan Diberikan Probiotik
}

\author{
Hematology Profile of Rattus norvegicus Infected by Enteropathogenic \\ Escherichia coli and Fed Probiotics
}

\author{
M. Astawan ${ }^{a, *}$, T. Wresdiyati ${ }^{\text {b, }, \text { I. I. Arief }}{ }^{c, \#, ~ \& ~ E . ~ S u h e s t i ~}{ }^{a}$ \\ aDepartemen Ilmu dan Teknologi Pangan, Fakultas Teknologi Pertanian, Institut Pertanian Bogor \\ Jln. Kamper, Kampus IPB Darmaga Bogor 16680 \\ ${ }^{\text {b}}$ Departemen Anatomi, Fisiologi dan Farmakologi, Fakultas Kedokteran Hewan, Institut Pertanian Bogor \\ 'Departemen Ilmu Produksi dan Teknologi Peternakan, Fakultas Peternakan, Institut Pertanian Bogor \\ \#Jln. Agatis, Kampus IPB Darmaga Bogor 16680 \\ (Diterima 07-06-2010; disetujui 10-03-2011)
}

\begin{abstract}
In Indonesia, diarrhea is the second leading cause of death in children after ISPA (Acute Respiratory Infection). This study aimed to test the ability of probiotic, Lactobacillus plantarum $2 \mathrm{C} 12$ and Lactobacillus acidophilus 2B4, as an indigenous anti-diarrhea in rats exposed to Enteropathogenic Escherichia coli (EPEC) and find out their impact on erythrocytes, hematocrit, hemoglobin, thrombocytes, and leukocytes. A total of 95 male rats Sparague Dawley strain were alocated into six treatment groups: (1) negative control, (2) L. plantarum 2C12, (3) L. acidophilus 2B4, (4) L. plantarum 2C12 + EPEC, (5) L. acidophilus 2B4 + EPEC, and (6) positive control (exposed to EPEC). Probiotics were given from day 1 up to 21 , whereas $10^{6} \mathrm{cfu} / \mathrm{ml}$ EPEC was administered orally from day 8 to 14 . On day 21 , the number of erythrocytes, hematocrit and hemoglobin were the lowest $(7.07 \mathrm{million} / \mu \mathrm{l} ; 39.13 \%$; $14.50 \mathrm{~g} / \mathrm{dl}$ ) in the positive group of rats. The positive control group had lower number of thrombocytes $(389$ thousand/ $\mu \mathrm{l})(\mathrm{P}<0.05)$ with the negative control and the L. plantarum $2 \mathrm{C} 12$ groups, but not significantly different to the other groups. The number of leucocytes in the positive control rats (4433 cell $/ \mu \mathrm{l})$ was lower $(\mathrm{P}<0.05)$ than that of the negative control, L. plantarum $2 \mathrm{C} 12$, and the L. acidophilus 2B4 groups, but no significant difference to the other groups. L. plantarum $2 \mathrm{C} 12$ had better ability than $L$. acidophilus $2 \mathrm{~B} 4$ in maintaining the number of erythrocytes, hematocrit, and hemoglobin of rat infected by EPEC.
\end{abstract}

Key words: L. plantarum 2C12, L. acidophilus 2B4, EPEC, hematology

\section{PENDAHULUAN}

Menurut de Roos \& Katan (2000), diare adalah penyebab kematian nomor empat dari seluruh penyakit di dunia. Diare di Indonesia adalah pembunuh balita nomor dua setelah ISPA (Infeksi Saluran Pernapasan Akut). Berdasarkan hasil Survei Kesehatan Rumah Tangga (SKRT 2008), sekitar 162.000 balita di Indonesia meninggal setiap tahun, atau sekitar 460 balita setiap harinya. Diare adalah suatu kondisi ketika seseorang buang air besar 3 kali atau lebih dalam satu hari, dan tinja atau feses yang keluar berupa cairan encer atau sedikit berampas, kadang juga disertai darah atau lendir.

Berdasarkan hasil penelitian Arief et al. (2008), didapatkan sepuluh spesies bakteri asam laktat (BAL) lokal yang diisolasi dari daging sapi mentah yang

\footnotetext{
* Korespondensi:

e-mail: mastawan@yahoo.com
}

mempunyai sifat dasar sebagai probiotik dan menghasilkan senyawa antimikroba. Kesepuluh BAL tersebut kemudian diuji berdasarkan daya hambat terhadap Enteropatogenik Escherichia coli (EPEC) dan ketahanan terhadap garam empedu sehingga diperoleh 2 jenis BAL, yaitu Lactobacillus plantarum 2C12 dan Lactobacillus acidophilus 2B4. Senyawa antimikroba yang dihasilkan oleh kesepuluh BAL tersebut mampu menghambat pertumbuhan bakteri enteropatogenik seperti Escherichia coli enterotoksigenik, Straphylococcus aureus, dan Salmonella typhimurium. Namun demikian, sifat fungsional lainnya khususnya sebagai pencegah penyakit gastroenteritis, misalnya diare akibat infeksi EPEC, belum pernah dicoba.

Bakteri asam laktat (BAL) yang diisolasi berpotensi sebagai probiotik. Kelebihan bakteri probiotik ini dibandingkan dengan BAL lainnya adalah mampu bertahan hidup, berkembang biak, berkompetisi dengan bakteri jahat, serta mengeluarkan zat antibakteri dalam saluran pencernaan manusia (meningkatkan kekebalan 
tubuh manusia) sehingga dapat menghambat pertumbuhan bakteri jahat, seperti bakteri penyebab diare di atas. BAL, seperti Lactobacillus dan Bifidobacterium merupakan kelompok bakteri yang umum digunakan sebagai mikroorganisme probiotik bagi konsumen (FAO, 2006).

Walaupun target utama bakteri probiotik adalah saluran pencernaan dan usus, namun beberapa penelitian membuktikan bahwa efek immunomodulator probiotik terhadap gambaran hematologik dapat dijelaskan secara sistematik. Secara spesifik, hal ini terlihat pada leukosit dan imunitas humoral yang hanya dapat diuji secara ex vivo. Beberapa bagian sistem imun telah diketahui dapat dipengaruhi oleh pemberian probiotik, termasuk limfosit (proliferasi, sekresi sitokin, dan sitotoksik selular); sistem imun bawaan (fagositosis, produksi radikal, sekresi enzim lisosim); aktivitas sel pembunuh alami dan sel natural killer (NK) serta antibodi (immunoglobulin level dan spesifik antigen) (Shahani \& Walker, 2000; Liong, 2007).

Bakteri probiotik yang diberikan secara oral mampu mempengaruhi sistem metabolisme tubuh (Hattingh \& Viljoen, 2001), termasuk juga status hematologi (Aboderin \& Oyetayo, 2006). Darah berfungsi mendistribusikan nutrisi, oksigen serta zat-zat lain ke semua organ, sehingga memungkinkan organ tubuh melakukan fungsinya. Fungsi darah dapat terganggu bila parameter darah tidak normal, akibatnya terjadi penyakit atau gangguan pada darah dan fungsi darah yang pada gilirannya dapat menyebabkan gangguan pada organ lain. Berdasarkan hal tersebut perlu dilakukan penelitian untuk mengetahui pemberian bakteri probiotik terhadap parameter darah yang meliputi jumlah eritrosit, jumlah leukosit, kadar hemoglobin, nilai hematokrit, dan jumlah trombosit.

Penelitian ini dilakukan untuk menguji kemampuan probiotik lokal berupa $L$. plantarum 2C12 dan $L$. acidophilus 2B4 sebagai antidiare pada tikus percobaan yang dipapar bakteri EPEC secara in vivo serta mengetahui dampaknya pada gambaran hematologik (eritrosit, hematokrit, hemoglobin, trombosit, dan leukosit).

\section{MATERI DAN METODE}

\section{Hewan Percobaan dan Pemberian Pakan}

Tikus jantan (Rattus norvegicus) galur Sprague Dawley umur 5-6 minggu dengan kisaran berat badan awal 120-130 g sebanyak 90 ekor hasil pengembangbiakan Badan POM RI digunakan pada penelitian ini. Tikus dibagi dalam 6 kelompok perlakuan (Tabel 1). Sebelum mendapatkan perlakuan, semua tikus diadaptasikan dengan kondisi kandang dan pakan selama tiga hari. Pemberian pakan yang sama dilanjutkan hingga hari ke-21. Sebelum percobaan, semua kelompok tikus diberi ransum standar ad libitum.

\section{Pemberian Bakteri Asam Laktat}

BAL diberikan secara oral menggunakan sonde dari hari ke-1 hingga ke-21. BAL yang diberikan adalah L. plantarum 2C12 dan L. acidophilus 2B4.
Kultur probiotik (L. plantarum 2C12 dan L. acidophilus 2B4) disimpan dalam bentuk agar miring pada suhu $4{ }^{\circ} \mathrm{C}$ (Arief et al., 2010). Kultur disegarkan pada media de Man Rogosa Sharp broth (MRSB, Oxoid) dan diinkubasi pada suhu $37{ }^{\circ} \mathrm{C}$ selama 24 jam sebagai kultur induk, yang selanjutnya dibiakkan kembali dengan cara yang sama sebagai kultur kerja. Kultur kerja kemudian dihitung populasinya sampai mencapai minimal $10^{9} \mathrm{cfu} / \mathrm{ml}$. Kultur kerja pada media MRSB kemudian diencerkan pada media $\mathrm{NaCl}$ fisiologis hingga mencapai populasi $10^{8} \mathrm{cfu} / \mathrm{ml}$ yang selanjutnya siap untuk dicekokkan ke tikus percobaan.

\section{Infeksi EPEC}

Tikus diare dipersiapkan dengan cara menginduksinya dengan bakteri EPEC. Kultur EPEC yang digunakan merupakan koleksi Fakultas Kedokteran Hewan Institut Pertanian Bogor dalam biakan agar miring. Pengujian anti-EPEC in vivo dilakukan sesuai meode Zoumpopoulou et al. (2008). Infeksi EPEC dilakukan menggunakan populasi $10^{6} \mathrm{cfu} / \mathrm{ml}$ sebanyak $1 \mathrm{ml}$ per hari mulai hari ke- 8 sampai ke-14, secara oral menggunakan sonde.

Kejadian diare tikus percobaan diamati dengan cara mengukur kadar air feses yang dikumpulkan pada hari ke-14 dan ke-21. Penentuan kadar air feses mengikuti prosedur analisis kadar air menurut AOAC (2005).

\section{Pengambilan Sampel Darah dan Analisis Hematologi}

Proses pengambilan sampel darah dilakukan melalui proses pembedahan. Pembedahan tikus dilakukan pada hari ke-7, 14, dan 21. Sampel darah dikoleksi melalui 'cardiac puncture' kemudian dimasukkan dalam tabung yang berisi EDTA. Proses pengambilan sampel darah dilakukan melalui proses pembedahan, karena selain sampel darah, organ-organ lain juga diambil, seperti limpa, usus, hati, dan ginjal untuk prosedur sediaan histologis yang tidak dibahas dalam tulisan ini.

Tabel 1. Kelompok perlakuan tikus percobaan

\begin{tabular}{ll}
\hline Kelompok tikus & \multicolumn{1}{c}{ Perlakuan } \\
\hline Kontrol negatif & $\begin{array}{l}\text { Tikus normal hanya diberi ransum } \\
\text { standar dan akuades }\end{array}$ \\
$\begin{array}{l}\text { L. plantarum } \\
\text { 2C12 }\end{array}$ & $\begin{array}{l}\text { Tikus diberi ransum standar, diiringi } \\
\text { pemberian BAL L. plantarum 2C12 }\end{array}$ \\
L. acidophilus 2B4 & $\begin{array}{l}\text { Tikus diberi ransum standar, diiringi } \\
\text { pemberian BAL L. acidophilus 2B4 }\end{array}$ \\
L. plantarum & $\begin{array}{l}\text { Tikus diberi ransum standar, diiringi } \\
\text { pemberian BAL L. plantarum 2C12 } \\
\text { dan diselingi dengan infeksi EPEC }\end{array}$ \\
L. acidophilus 2B4 & $\begin{array}{l}\text { Tikus diberi ransum standar, diiringi } \\
\text { pemberian BAL L. acidophilus 2B4 dan } \\
\text { diselingi dengan infeksi EPEC }\end{array}$ \\
Kontrol positif & $\begin{array}{l}\text { Tikus diberi ransum standar dan } \\
\text { infeksi EPEC }\end{array}$ \\
\hline
\end{tabular}

$\mathrm{EPEC}=$ Eschericia coli enteropatogenik. 
Kondisi hematologi dianalisa sesuai metode Aboderin \& Oyetayo (2006). Analisis dilakukan menggunakan hematology analyzer Hemavet HV950FS. Komponen darah yang dianalisa adalah jumlah eritrosit, nilai hematokrit, kadar hemoglobin, jumlah leukosit, dan jumlah trombosit.

\section{Rancangan Percobaan dan Analisis Data}

Tikus dialokasikan ke dalam enam perlakuan pada rancangan acak lengkap. Data dianalisa menggunakan ANOVA. Jika perlakuan berpengaruh nyata, maka perbedaan nilai tengah diuji dengan uji Duncan (Steel \& Torrie, 1995).

\section{HASIL DAN PEMBAHASAN}

\section{Kejadian Diare pada Tikus Terinfeksi EPEC}

Feses tikus kelompok kontrol positif menjadi lembek pada hari ke-14, yang ditunjukkan dengan kadar air feses yang mencapai $63,95 \%$. Kadar air tersebut lebih tinggi daripada feses tikus yang diinfeksi EPEC tetapi diberikan BAL (Tabel 2). Kadar air feses pada tikus kelompok L. plantarum 2C12 + EPEC dan kelompok $L$. acidophilus 2B4 + EPEC, masing-masing sebesar 48,22\% dan $46,63 \%$. Tikus yang sehat (tanpa diinfeksi EPEC) tidak mengalami diare yang ditunjukkan oleh kadar air 49,16\%-52,07\%, yaitu pada tikus kelompok kontrol negatif, kelompok L. plantarum 2C12 dan kelompok $L$. acidophilus 2B4. Spehlman et al. (2009) melaporkan bahwa kadar air feses normal adalah di bawah $60 \%$, sedangkan diare pada tikus ditandai feses lembek dengan kadar air di atas $60 \%$, dan diare sangat parah dengan feses sangat cair yang berkadar air di atas $80 \%$, .

Semua tikus yang diinfeksi dengan EPEC termasuk kelompok tikus yang dicekok dengan BAL cenderung mengalami diare pada hari ke-21. Tikus yang diinfeksi oleh EPEC tanpa pemberian BAL mengalami diare yang lebih parah. Hal ini dapat dilihat dari kadar air feses pada hari ke-21, tikus kelompok kontrol positif mempunyai kadar air feses 68,92\%, sedangkan tikus kelompok L. plantarum 2C12 + EPEC dan kelompok $L$. acidophilus 2B4 + EPEC adalah 57,75 \% dan 57,37\%. Tikus yang sehat (kelompok kontrol negatif, kelompok $L$. plantarum 2C12 dan kelompok L. acidophilus 2B4), kadar air fesesnya berkisar $46,00 \%-53,20 \%$.

Tabel 2. Kadar air feses tikus percobaan $(\% b b)$

\begin{tabular}{lll}
\hline \multicolumn{1}{c}{ Kelompok tikus } & Hari ke- 14 & Hari ke-21 \\
\hline Kontrol negatif & $52,07 \pm 1,07^{\mathrm{a}}$ & $53,20 \pm 1,23^{\mathrm{b}}$ \\
L. plantarum 2C12 & $49,20 \pm 1,25^{\mathrm{a}}$ & $46,00 \pm 3,34^{\mathrm{a}}$ \\
L. acidophilus 2B4 & $49,16 \pm 0,98^{\mathrm{a}}$ & $48,30 \pm 1,67^{\mathrm{a}}$ \\
L. plantarum 2C12 +EPEC & $48,22 \pm 1,82^{\mathrm{a}}$ & $57,75 \pm 3,72^{\mathrm{b}}$ \\
L. acidophilus 2B4 + EPEC & $46,63 \pm 3,20^{\mathrm{a}}$ & $53,37 \pm 3,54^{\mathrm{b}}$ \\
Kontrol positif & $63,95 \pm 2,45^{\mathrm{b}}$ & $68,92 \pm 3,41^{\mathrm{c}}$ \\
\hline
\end{tabular}

Keterangan: superskrip berbeda pada kolom yang sama menunjukkan berbeda nyata $(\mathrm{P} \triangleleft 0,05)$. BAL= bakteri asam laktat.
Bakteri asam laktat memberikan manfaat positif bagi kesehatan, khususnya menjaga keseimbangan mikroflora saluran pencernaan. Manfaat kesehatan yang berkaitan dengan bakteri asam laktat adalah mengendalikan bakteri patogen dalam saluran pencernaan (Collado et al., 2007). EPEC merupakan salah satu bakteri patogen yang dapat menyebabkan diare. Perlekatan EPEC pada sel mukosa usus menyebabkan terjadinya perubahan struktur sel, kemudian melakukan invasi menembus sel epitel usus.

EPEC merupakan E. coli penyebab diare yang tidak disebabkan oleh toksin namun berkemampuan melakukan penempelan yang sangat kuat dan menyebabkan terjadinya luka pada sel epitel usus (Adlberberth et al., 2000). Luka pada sel epitel usus yang disebabkan oleh penempelan EPEC menyebabkan gangguan homeostatis di mukosa usus yang menyebabkan terjadinya pengeluaran cairan berlebihan ke usus sehingga menyebabkan diare. Lu \& Walker (2001) menyatakan bahwa pencegahan diare yang disebabkan oleh EPEC diawali dengan pencegahan translokasi EPEC ke sel epitel usus oleh probiotik. Probiotik mampu berkompetisi dengan EPEC dalam memanfaatkan nutrien penting dalam usus lalu mampu tumbuh dan mendapatkan sisi penempelan pada sel epitel usus. Setelah berhasil menempel dan berkolonisasi pada sel epitel usus, probiotik memproduksi dan mengeluarkan senyawa metabolit antimikroba yang mampu menghambat pertumbuhan EPEC di usus.

\section{Eritrosit}

Kelompok tikus kontrol positif memiliki jumlah eritrosit lebih rendah $(\mathrm{P} \varangle$,05) daripada kelompok kontrol negatif dan kelompok yang diberi BAL, baik dengan EPEC maupun tanpa EPEC (Gambar 1). Bakteri probiotik yang sifatnya bakteriostatik bahkan bakterisidal, targetnya adalah melindungi membran plasma yang berperan dalam pemasukan nutrien dan pengeluaran sisa metabolisme. Kerusakan membran sel akibat adanya bakteri patogen, akan mengganggu sifat permeabilitas dinding sel sehingga sel akan mengalami kebocoran dan kehilangan beberapa metabolit penting yang pada akhirnya akan berakhir dengan berkurangnya jumlah sel eritrosit (Aboderin \& Oyetayo, 2006). Namun demikian, pada hari ke-21 jumlah eritrosit semua kelompok tikus kecuali kelompok tikus kontrol positif, masih berada dalam kisaran normal, yaitu 7,2-9,6 juta/ $\mu$ (Aboderin \& Oyetayo, 2006).

Bakteri EPEC agar dapat berkolonisasi pada saluran pencernaan, pertama kali harus melekat pada glikokonjugat yang ada pada membran mikrovili. Glikokonjugat merupakan terminal gula pada sisi rantai oligosakarida yang terletak pada membran mikrovili. Glikokonjugat ini dapat berupa glikoprotein atau glikolipida. Salah satu glikoprotein yang digunakan EPEC agar dapat berkolonisasi pada sel mukosa usus adalah eritropoietin. Hal tersebut yang menyebabkan peningkatan aktivitas hormon eritropoietin untuk merangsang pembentukan eritroblas dari sel-sel hematopoetik yang akhirnya menjadi eritrosit. Meningkatnya hormon ini diakibatkan peran ginjal, tetapi tempat pembentukan hormon ini 
belum diketahui secara pasti. Hormon eritropoietin juga dapat merangsang proses pembelahan sel menjadi lebih cepat (Bourlioux et al., 2003).

\section{Hematokrit}

Hematokrit adalah persentase eritrosit di dalam $100 \mathrm{ml}$ darah. Proporsi eritrosit dan hematokrit tikus (Gambar 1 dan 2) bernilai tetap sekitar 1:5, meskipun mendapat perlakuan berbeda. Hal ini berarti bahwa diare tidak mengganggu rasio eritrosit dan hematokrit.

Kelompok tikus kontrol positif memiliki nilai hematokrit yang lebih rendah $(\mathrm{P} \varangle 0,05)$ daripada kelompok tikus normal (kontrol negatif) dan tikus yang diberi BAL dengan atau tanpa EPEC (Gambar 2). Penurunan nilai hematokrit pada kelompok kontrol positif kemungkinan disebabkan kerusakan mukosa usus dan diare sehingga nutrien tidak dapat diserap dengan baik.

Nilai hematokrit kelompok L. plantarum 2C12 dan $L$. plantarum 2C12 + EPEC, nyata lebih tinggi dibandingkan dengan kelompok kontrol negatif, L. acidophilus 2B4 dan L. acidophilus 2B4 + EPEC. Hal ini menunjukkan bahwa L. plantarum 2C12 lebih efektif mempertahankan nilai hematokrit akibat pengaruh infeksi EPEC dibandingkan L. acidophilus 2B4. Lactobacillus plantarum umumnya lebih tahan terhadap asam dan merupakan bakteri penghasil hidrogen peroksida tertinggi dibandingkan BAL lainnya dan juga menghasilkan bakterisidal (Hata et al., 2010). Semua kelompok tikus umumnya masih menunjukkan nilai hematokrit dalam kisaran normal, yaitu 39\%-53\% (Aboderin \& Oyetayo, 2006).

\section{Hemoglobin}

Kelompok tikus kontrol positif memiliki jumlah hemoglobin lebih rendah daripada kelompok tikus kontrol negatif dan yang diinfeksikan BAL dengan, atau tanpa EPEC (Gambar 3). Kullisaar et al. (2001) menjelaskan bahwa zat besi (Fe) yang diserap dari lumen usus akan berikatan langsung dengan apotransferin yang membawa Fe menuju sel hati untuk digunakan dalam pembentukan hemoglobin. Adanya EPEC yang mampu merusak dinding usus mengakibatkan lumen usus tidak mampu menyerap zat besi dengan baik, sehingga pembentukan hemoglobin akan terhambat.

Tingginya kadar hemoglobin kelompok L. plantarum 2C12 dan L. plantarum 2C12 + EPEC terkait dengan kemampuannya menghasilkan antimikroba yang dapat menghambat pertumbuhan EPEC sehingga mengurangi kerusakan epitel usus. Bakteri patogen seperti EPEC dapat merusak permeabilitas membran sel dan akan berakhir dengan rusaknya dinding sel, sehingga berakibat keluarnya hemoglobin dari sel dan menurunkan kadar hemoglobin (Aboderin \& Oyetayo, 2006). L. plantarum 2C12 lebih efektif mempertahankan bahkan meningkatkan jumlah hemoglobin dibandingkan L. acidophilus 2B4 (Gambar 3). Namun demikian, semua kelompok tikus masih menunjukkan kadar hemoglobin dalam kisaran

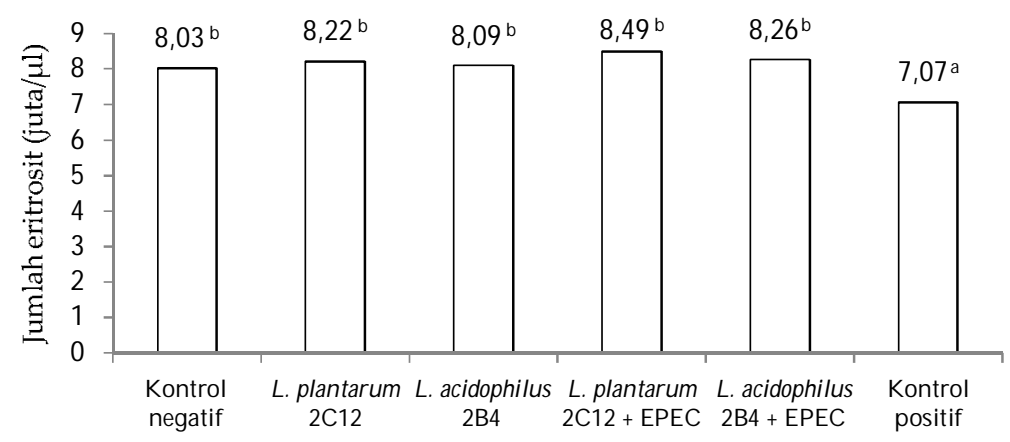

Gambar 1. Rataan jumlah eritrosit tikus perlakuan dan kontrol (juta/ $\mu$ l) pada hari ke-21; nilai yang diikuti oleh huruf yang berbeda menunjukkan berbeda nyata $(\mathrm{P} \varangle, 05)$.; EPEC=Enteropatogenik Escherichia coli.

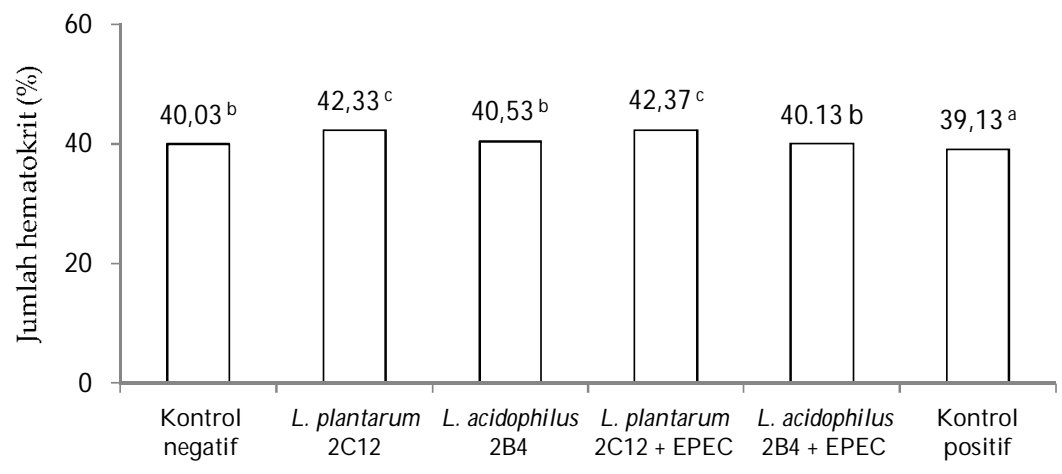

Gambar 2. Rataan nilai hematokrit tikus (\%) perlakuan dan kontrol pada hari ke-21; nilai yang diikuti oleh huruf yang berbeda menunjukkan berbeda nyata $(\mathrm{P} \varangle 0,05)$; $\mathrm{EPEC}=$ Enteropatogenik Escherichia coli. 
normal, yaitu 12-17.5 g/dl pada hari ke-21 (Dranville, 1972).

\section{Trombosit}

Kelompok kontrol positif memiliki jumlah trombosit lebih rendah daripada kelompok kontrol negatif $(\mathrm{P} \varangle$,05) (Gambar 4). Aktivitas patogen dari EPEC mampu melisis dinding mukosa usus yang mengakibatkan pendarahan. Bila terjadi luka, maka trombosit jaringan yang rusak akan mengeluarkan tromboplastin yang bereaksi dengan protrombin dan kalsium membentuk trombin. Trombin akan bereaksi dengan fibrinogen membentuk fibrin yang akan menutupi jaringan yang terluka. Akibatnya akan terjadi penurunan jumlah trombosit dalam sirkulasi darah pada kelompok kontrol positif.

Pemberian L. plantarum 2C12 mampu mempertahankan jumlah trombosit dalam jumlah normal. $L$. plantarum merupakan probiotik yang mampu melekat pada sel epitel dan memproduksi metabolit yang berperan menjaga dan mempertahankan mikroflora usus. Probiotik juga mampu melepaskan sejumlah asam amino bebas dan mensintesa vitamin yang sangat dibutuhkan oleh pertumbuhan inangnya (Parvez et al., 2006).

\section{Leukosit}

Kelompok tikus kontrol positif memiliki leukosit yang nyata lebih rendah $(\mathrm{P} \varangle 0,05)$ dibandingkan dengan

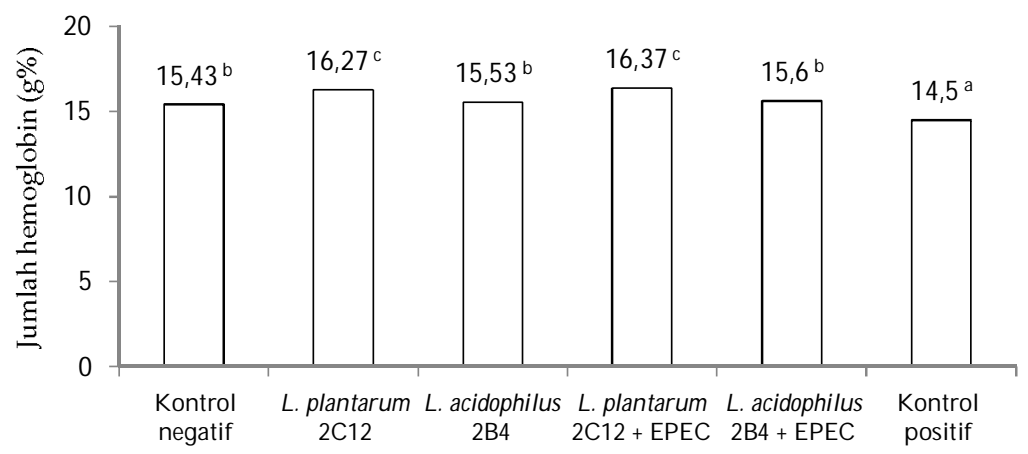

Gambar 3. Rataan kadar hemoglobin tikus perlakuan dan kontrol (g/dl) pada hari ke-21. Superskrip berbeda menunjukkan berbeda nyata $(\mathrm{P}<0,05) ; \mathrm{EPEC}=$ Enteropatogenik Escherichia coli .

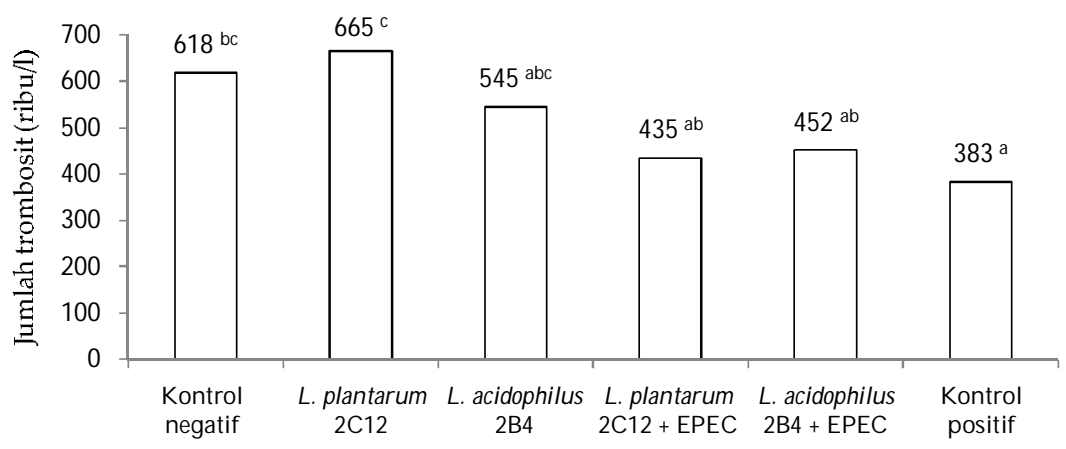

Gambar 4. Rataan trombosit tikus perlakuan dan kontrol (ribu/ $\mu$ l) pada hari ke-21. Superskrip berbeda menunjukkan berbeda nyata $(\mathrm{P}<0,05) ; \mathrm{EPEC}=$ Enteropatogenik Escherichia coli.

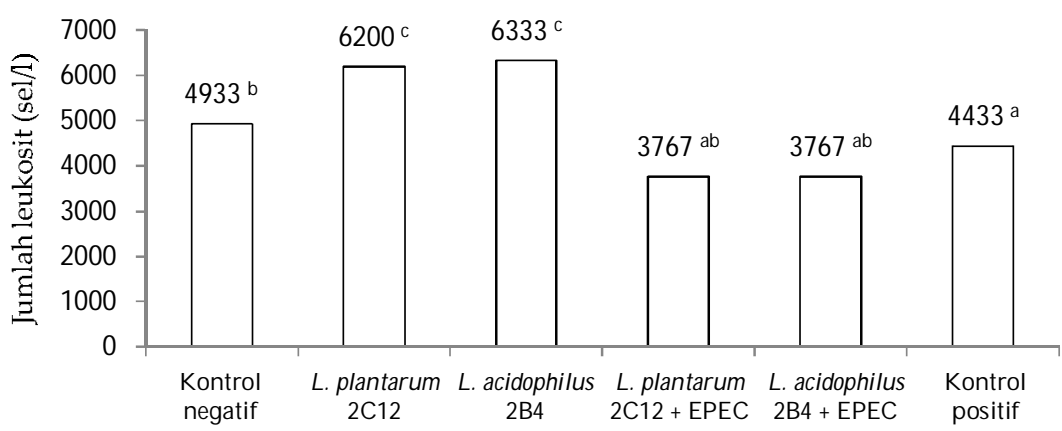

Gambar 5. Rataan leukosit tikus perlakuan dan kontrol (sel/) pada hari ke-21. Superskrip berbeda menunjukkan berbeda nyata $(\mathrm{P}<0,05) ; \mathrm{EPEC}=$ Enteropatogenik Escherichia coli. 
kelompok kontrol negatif, L. plantarum 2C12 dan L. acidophilus 2B4 (Gambar 5).

Kisaran jumlah leukosit normal tikus, yaitu 5.00025.000 sel/ (Aboderin \& Oyetayo, 2006). Peningkatan jumlah leukosit pada kelompok tikus yang diberi probiotik, baik L. plantarum 2C12, maupun L. acidophilus 2B4 disebabkan probiotik mampu bertindak sebagai immonomodulator (Tuomola et al., 2001; Agostoni et al., 2004). Beberapa strain bakteri asam laktat yang bersifat probiotik menstimulasi sistem imun, seperti memperbaiki aktivitas makrofag, meningkatkan antibodi, mengaktifkan sel natural killer. Bakteri asam laktat probiotik dapat meningkatkan respon imun, baik spesifik maupun nonspesifik, serta mampu mengendalikan infeksi saluran usus (Perdigon et al., 2001; Bhatia \& Rani, 2008).

Penurunan jumlah leukosit pada tikus kelompok L. plantarum 2C12 + EPEC, L. acidophilus 2B4 + EPEC, dan tikus kontrol positif, dimungkinkan karena adanya luka pada mukosa usus yang cukup serius akibat infeksi EPEC pada mukosa intestinal sehingga leukosit terpakai untuk pertahanan tubuh. Kondisi tersebut mengakibatkan jumlah leukosit pada sirkulasi darah berkurang jumlahnya.

\section{KESIMPULAN}

Pemberian L. plantarum 2C12 dan L. acidophilus 2B4 pada tikus yang diinfeksi EPEC dapat mencegah kejadian diare, mempertahankan jumlah eritrosit, nilai hematokrit, serta kadar hemoglobin tikus dalam jumlah normal, namun belum mampu mempertahankan jumlah trombosit dan leukosit. L. plantarum 2C12 mempunyai kemampuan yang lebih besar daripada L. acidophilus 2B4 dalam mempertahankan jumlah eritrosit, nilai hematokrit, dan kadar hemoglobin tikus yang diinfeksi EPEC.

\section{UCAPAN TERIMA KASIH}

Penulis mengucapkan terima kasih kepada Direktorat Penelitian dan Pengabdian kepada Masyarakat, Direktorat Jenderal Pendidikan Tinggi, Kementerian Pendidikan Nasional Republik Indonesia, yang telah memberikan dana penelitian melalui Hibah Kompetensi, Nomor Kontrak: 409/SP 2 H/DP2MNI/2010, tanggal 11 Juni 2010, atas nama Made Astawan.

\section{DAFTAR PUSTAKA}

Aboderin, F. I. \& V.O. Oyetayo. 2006. Haematological Studies of Rats Fed Different Doses of Probiotic, Lactobacillus plantarum, isolated from fermenting corn slurry. Pakistan J of Nutrition 5: 102-105.

Adlerberth, I, M. Cerquetti, I. Poilane, A. Wold, \& A. Collignon. 2000. Mechanisms of colonization and colonization resistance of the digestive tract. Part 1: bacteria host interactions. Microbial Ecology in Health and Disease. 2 : 223-239.

Agostoni, C., I. Axelsson, C. Braegger, O. Goulet, B. Koletzko, K. F. Michaelsen, J. Rigo, R. Shamir, H. Szajewska, D. Turck \& L. T. Weaver. 2004. Probiotic bacteria in dietetic products for infants: a commentary by the ESPHGHAN Committee on Nutrition. J. Pediatr. Gastroenterol. Nutr. 28: 365-374.
AOAC. 2005. Official Methods of Analysis in The Association of Official Agricultural Chemist. Association of Official Agricultural Chemist, Washington D.C.

Arief, I. I., B. Sri Laksmi Jenie, M. Astawan, \& A. B. Witarto. 2010. Efektivitas probiotik Lactobacillus plantarum 2C12 dan Lactobacillus acidophilus 2B4 sebagai pencegah diare pada tikus percobaan. Med. Pet. 33: 137-143.

Arief, I. I., R. R. A. Maheswari, T. Suryati, Komariah, \& S. Rahayu. 2008. Kualitas mikrobiologi sosis fermentasi daging sapi dan domba yang menggunakan kultur kering Lactobacillus plantarum 1B1 dengan umur yang berbeda. Med. Pet. 31: 36-43.

Bhatia, A, \& U. Rani. 2008. Immunomodulatory effect of $S$. thermophilus: an experimental study. Calicut Medical Journal 6(2): e.

Bourlioux, P., B. Koletzko, F. Guarner, \& V. Braesco. 2003. The intestine and its microflora are partners for the protection of the host: report on the Danone symposium 'The Intelligent Intestine', held in Paris, June 14, 2002. Am. J. Cli.n Nutr. 78: 675-683.

Collado, M. C., I. S. Surono, J. Meruluoto, \& S. Salminen. 2007. Potential probiotic characteristics of Lactobacillus and Enterococcus strains isolated from traditional dadih fermented milk against pathogen intestinal colonization. J Food Protect. 70: 700-705.

De Roos, N. M. \& M. B. Katan. 2000. Effects of probiotics bacteria on diarrhea, lipid metabolism, and carcinogenesis. Am. J Clin Nutr 71 : 405-411.

[FAO] Food and Agriculture Organization. 2006. Probiotics in food health and nutritional properties and guidelines for evaluation. FAO Food and Nutrition Paper. World Health Organization and Food and Agriculture Organization of The United Nations, Roma.

Gross, G., J. Wildner, A. Schoneville, J. L. W. Rademaker, Rvd. Meer, \& J. Snel. 2008. Probiotic Lactobacillus plantarum $299 \mathrm{v}$ doesnot unfavorable phytohematoglutinin induced changes in the rat intestinal microbiota. Appl. Environ. Microbiol 74 : 5224-5249.

Hata, T., R. Tanaka, \& S. Ohmomo. 2010. Isolation and characterization of plantaricin ASM 1 : a new bacteriocin produced by Lactobacillus plantarum A-1. Int. J. Food Microbiol. 137 :94-99.

Hatting, L. A. \& B. C. Viljoen. 2001. Yogurt as probiotic carrier food. Int. Dairy J. $11: 1-17$

Kullisaar, T., M. Zilmer, M. Mikelsaar, T. Vihelm, H. Annuk, C. Kamane, \& A. Klik. 2001. Two antioxidant Lactobacilli strains as promising probiotics. Food Microbiol J. 72: 215-224.

Liong, M. 2007. Probiotics: a critical review of their potential role as antihypertensives, immune modulators, hypocholesterolemics, and perimenopausal treatments. Nutrition Reviews 65: 316-328.

Lu, L. \& W. A. Walker. 2001. Pathologic and physiologic interactions of bacteria with the gastrointestinal epithelium. Am. J. Clin. Nutr. 73 (suppl): 1124S-1130S.

Parvez, S., K. A. Malik, S. A. Kong, \& H. Y. Kim. 2006. Probiotics and their fermented food products are beneficial for health. Review article. J. Appl. Microbiol. 100: 1171-1185.

Perdigon, G. R. Fuller, \& R. Raya. 2001. Lactic acid bacteria and their effect on immune system. Curr. Issues. Intest. Microbiol. 2 : 27-42.

Shahani, U. \& W. A. Walker. 2000. Adverse host responses to bacterial toxins in human infants. J. Nutr. 130: 420S-425S.

Spehlmann, M. E., S. M. Dann, P. Hruz, E. Hanson, D. F. Mc.Cole, \& L. Eckmann. 2009. CXCR2-dependent mucosal neutrophil influx protects against colitis-associated diarrhea caused by an attaching/efficacing lesion-forming bacterial pathogen. J Immunology 183: 3333-3343. 
Steel, R. G. D. \& J. H. Torrie. 1995. Principles and Procedures of Statistic. A Biometrical Approach. ${ }^{\text {nd }}$ edition. Mc Graw Hill Book Co., New York.

Survei Kesehatan Rumah Tangga (SKRT). 2008. Kasus Diare di Indonesia. Survei Kesehatan Rumah Tangga, Indonesia.

Tuomola, E., R. Crittenden, M. Playne, I. Isolauri, \& S. Salminen. 2001. Quality assurance criteria for probiotic bacteria. Am. J. Clin. Nutr. 73 (suppl): 393S-398S.
Zoumpopoulou, G., B. Foligne, K. Christodoulou, C. Grangette, B. Pot, \& E. Tsakalidou. 2008. Lactobacillus acidophilus ACA-DC 179 displays probiotic potential in vitro and protects against trinitrobenzene sulfonic acid (TNBS)-induced colitis and Salmonella infection in murine models. Int. J. Food Microbiol. 121: 18-26. 